Western University

Scholarship@Western

Obstetrics \& Gynaecology Publications

Obstetrics \& Gynaecology Department

$1-1-2000$

Effects of superovulated heifer diet type and quantity on relative mRNA abundances and pyruvate metabolism in recovered embryos.

CWrenzycki

P De Sousa

EW Overström

R T Duby

D Herrmann

See next page for additional authors

Follow this and additional works at: https://ir.lib.uwo.ca/obsgynpub

Part of the Obstetrics and Gynecology Commons

Citation of this paper:

Wrenzycki, C; De Sousa, P; Overström, E W; Duby, R T; Herrmann, D; Watson, A J; Niemann, H; O'Callaghan, D; and Boland, M P, "Effects of superovulated heifer diet type and quantity on relative mRNA abundances and pyruvate metabolism in recovered embryos." (2000). Obstetrics \& Gynaecology Publications. 65.

https://ir.lib.uwo.ca/obsgynpub/65 
Authors

C Wrenzycki, P De Sousa, E W Overström, R T Duby, D Herrmann, A J Watson, H Niemann, D O'Callaghan, and M P Boland 


\title{
Effects of superovulated heifer diet type and quantity on relative mRNA abundances and pyruvate metabolism in recovered embryos
}

\author{
C. Wrenzycki ${ }^{1}$, P. De Sousa ${ }^{2}$, E. W. Overström ${ }^{3}$, R. T. Duby ${ }^{4}$, D. Herrmann ${ }^{1}$, A. J. Watson ${ }^{5}$, \\ H. Niemann ${ }^{1}$, D. O'Callaghan ${ }^{6}$ and M. P. Boland ${ }^{7}$ \\ ${ }^{1}$ Department of Biotechnology, Institut für Tierzucht und Tierverhalten (FAL), Mariensee, 31535 Neustadt, Germany; ${ }^{2}$ Roslin Bio-Med, \\ Roslin Institute, Roslin, UK; ${ }^{3}$ Departments of Biomedical Sciences and Anatomy and Cellular Biology, Tufts University, MA, USA; \\ ${ }^{4}$ Department of Veterinary and Animal Sciences, University of Massachusetts, MA, USA; ${ }^{5}$ Departments of Obstetrics and Gynaecology \\ and Physiology, University of Western Ontario, London, Ontario, Canada; ${ }^{6}$ Faculty of Veterinary Medicine and ${ }^{7}$ Faculty of Agriculture, \\ University College Dublin, Ireland
}

\begin{abstract}
This study investigated the effects of quantity and type of diet fed to superovulated donor heifers on molecular and metabolic indices of embryonic development. These effects included the relative abundances of mRNAs for the $\alpha 1$ subunit of $\mathrm{Na} / \mathrm{K}$-ATPase and the antioxidant enzyme $\mathrm{Cu} / \mathrm{Zn}-\mathrm{SOD}$, as well as pyruvate utilization in bovine morulae and blastocysts developed in vivo. Heifers were fed a daily ration of either grass silage and a citrus-beet pulp-based concentrate or grass silage and a barley-based concentrate for 116 days, both at $3 \mathrm{~kg}$ per day or ad libitum. In embryos derived from heifers fed the pulp-based diets, the relative abundances of the transcripts were not affected by either day of collection or quantity of diet. In embryos derived from heifers fed the barley-based diets, the relative abundances of the $\mathrm{Na} / \mathrm{K}$-ATPase transcripts were also not changed by these main effects, while the relative abundances of the $\mathrm{Cu} / \mathrm{Zn}-\mathrm{SOD}$ transcripts were affected by day of collection and by the quantity of diet. Pyruvate metabolism was affected by day of collection, and was significantly increased in day 8 embryos compared with day 7 and day 6 embryos. Diet quantity did not affect pyruvate utilization, whereas diet type did increase pyruvate metabolism in the barley group when compared with the pulp group. The results of this study show for the first time that molecular and metabolic variations may exist in embryos derived in vivo and developed in donor heifers on nutritional regimens differing in type and quantity. Differences in embryos collected on different developmental days may be attributed to varying cell numbers. Alterations in the relative abundances of the $\mathrm{Cu} / \mathrm{Zn}-\mathrm{SOD}$ transcripts and pyruvate metabolism caused by the quantity of diet fed to the donor animal were likely to have been due to alterations in metabolic end products that accumulate in reproductive tract fluids, whereas differences in embryonic metabolism caused by type of diet are related to the composition of the diet. These findings characterize embryos produced in vivo at the molecular level, indicating that the molecular markers used in the present study can differentiate between populations of embryos produced under different nutritional regimens and determine conditions conducive to the production of good quality embryos.
\end{abstract}

\section{Introduction}

Superovulation of donors provides multiple embryos for the embryo transfer industry (Boland et al., 1991; Armstrong, 1993). Despite major research initiatives to enhance and standardize the superovulatory response to exogenous gonadotrophins, animal to animal variation in number and quality of embryos remains a problem (Goulding et al., 1996; Kelly et al., 1997). Several factors, such as season, breed, type

Received 1 February 1999. of gonadotrophin and the presence or absence of a dominant follicle, contribute to the variable number and quality of embryos produced (Armstrong, 1993; Bungartz and Niemann, 1994). In superovulated beef heifers, an increase in concentrate intake from $3 \mathrm{~kg}$ per day to ad libitum reduced the number of ovulations and provided fewer good quality embryos (Mantovani et al., 1993). The type of diet fed before superovulation also affects superovulatory response and embryo quality. Heifers fed a high concentrate-low fibre diet before superovulation had fewer high quality embryos 
(Yaakub et al., 1999). Similarly, rations of high rumendegradable protein decreased fertilization rates and preimplantation development (Blanchard et al., 1990). Thus, diet type, either in terms of energy source or protein content, can alter embryo yields and survival. The quantity of the food can also affect other parameters of the reproductive response, such as follicle size and progesterone concentrations (Murphy et al., 1991; Nolan et al., 1998).

The main energy substrates used by ruminants are volatile fatty acids (VFA) which are produced in the rumen. The type of concentrate fed affects rumen fermentation, with VFA profiles differing between cattle fed on starch-based or fibrebased concentrate (Moloney et al., 1994). The relative amounts of each VFA produced are diet-dependent, but rapidly fermented concentrate supplements tend to favour the production of propionate, and the more slowly fermented fibre-based diets favour acetate production (Sloan et al., 1988). Propionate is the main precursor of glucose synthesis in the liver. Glucose, amino acids or nutrientrelated metabolites, such as insulin, growth hormone, and the insulin-like growth factors and their binding proteins, have been postulated to operate at the ovarian level and to support the growth of the gonadotrophin-dependent follicles by reducing the amount of FSH required for follicle growth (Downing and Scaramuzzi, 1991). Bovine embryos are sensitive to glucose, as high concentrations in culture media inhibit embryo development in vitro (Takahashi and First, 1992).

The gene transcripts analysed in the present study are known to play essential roles during preimplantation development. Na/K-ATPase is a key enzyme for blastocyst development, mediating fluid transfer across the outer blastomeres to form a fluid-filled cavity (Watson, 1992, Kidder, 1993). In bovine embryos produced in vitro, transcripts encoding multiple isoforms of both the $\alpha$ and $\beta$ subunits of $\mathrm{Na} / \mathrm{K}$-ATPase are expressed throughout early development (Betts et al., 1997). A similar transcription pattern was detected for the antioxidant enzyme, $\mathrm{Cu} / \mathrm{Zn}$ SOD (Harvey et al., 1995), which is involved in protection from oxidative stress.

Another accepted marker of embryo quality is energy metabolism (Rieger, 1984, 1992; Overström, 1996; Gardner, 1998). Temporal, stage-specific pathways of energy metabolism have been investigated and metabolic activity may provide an objective means to assess the viability of embryos (Rieger, 1992). The patterns of uptake and metabolic utilization of energy substrates, such as pyruvate, lactate, glucose and glutamine, have been determined in bovine embryos (Thompson et al., 1996).

Given the reported effects of diet type and quantity on embryo quality after superovulation and the effects of diet type and quantity on energy metabolism in cattle, the purpose of this experiment was to evaluate the effects of quantity and type of diet on the relative abundance of two different gene transcripts and pyruvate metabolism in cattle embryos recovered at the morula and blastocyst stages after superovulatory treatment. While in vitro culture conditions can have profound effects on the expression of important genes in developing rodent and bovine embryos (Ho et al., 1994, 1995; Morita et al., 1994; Shim et al., 1996; Wrenzycki et al.,
1996, 1998a, 1999; Koerber et al., 1998), the effects of nutrition regimens on gene expression and metabolism in bovine embryos collected from superovulated donors have not yet been reported. The nutritional model used was designed to provide differing amounts ( $3 \mathrm{~kg}$ per day versus ad libitum) and types (starch (barley)-based versus sugar (citrus-beet pulp)based) of concentrate supplement to alter rumen metabolism. The heifers were superovulated to produce adequate embryos from the nutritionally treated heifers.

\section{Materials and Methods}

\section{Animals and treatments}

The nutritional and superovulatory treatments were described by Yaakub et al. (1999). Briefly, seventy-six continental crossbred heifers of approximately $500 \mathrm{~kg}$ live weight were offered grass silage supplemented with either barley concentrate at $3 \mathrm{~kg}$ per day $(n=20)$ or ad libitum $(n=$ $19)$, or a citrus-beet pulp concentrate at $3 \mathrm{~kg}$ per day $(n=18)$, or ad libitum $(n=19)$ for 116 days. Both concentrates were formulated to contain $14 \%$ crude protein. The major ingredients of the barley concentrate consisted of $80 \%$ barley, $12 \%$ soybean meal, $5 \%$ molasses, and citrus-beet pulp concentrate consisted of $31.9 \%$ citrus pulp, 31.9\% molassed beet pulp, $18 \%$ maize gluten and $12 \%$ soybean meal. Grass silage contained $12.1 \%$ crude protein, with a $\mathrm{pH}$ of 4.4 and $18.2 \%$ dry matter. Silage intake for heifers offered $3 \mathrm{~kg}$ concentrates per day was ad libitum, but for heifers offered ad libitum concentrate silage intake was limited to approximately $1 \mathrm{~kg}$ dry matter per day. The diets were chosen because the carbohydrate metabolism for starch (barley)-based and sugar-fibre (citrus-beet pulp)-based energy sources would vary significantly in the rumen, resulting in different fatty acid production profiles.

\section{Synchronization of oestrus, superovulation and embryo recovery}

Heifers were treated for 7 days with an intravaginal progesterone-releasing device containing $1.9 \mathrm{~g}$ progesterone (CIDR-B, InterAg, NZ) after 100 days on the treatment diets. Heifers received a total of $265 \mathrm{mg}$ NIH-FSH-P1 equivalent (pFSH, Folltropin-V, Vetrepharm Canada, London, Ontario) administered over 8 injections at $12 \mathrm{~h}$ intervals. The last two injections were given at 12 and $24 \mathrm{~h}$ after CIDR withdrawal. Heifers received a prostaglandin $\mathrm{F}_{2 \alpha}$ analogue $(15 \mathrm{mg}$ luprostiol, PG, Prosolvin; Intervet, Boxmeer) injection with the fifth injection of $\mathrm{pFSH}$. Heifers were artificially inseminated twice, at 56 and $72 \mathrm{~h}$ after CIDR withdrawal, without reference to oestrus, using frozen-thawed semen from a single bull with proven fertility. Embryos were recovered from excised reproductive tracts according to the procedures reported by Goulding et al. (1994) on day 6, 7 or 8 after first insemination into PBS (Oxoid Ltd, Basingstoke) containing 5\% fetal calf serum (FCS, Gibco, Grand Island, NY) and transferred into CR-2 collection medium (114.7 $\mathrm{mmol} \mathrm{NaCl} 1^{-1} 1 \mathrm{mmol} \mathrm{KCl}^{-1}, 26.2 \mathrm{mmol} \mathrm{NaHCO}_{3}, 5.5 \mathrm{mmol}$ 
hemi-calcium lactate $1^{-1}, 0.4 \mathrm{mmol}$ pyruvate $\mathrm{l}^{-1}, 500 \mathrm{mmol}$ glutamine $1^{-1}, 1 \% \mathrm{BSA}$, and $0.1 \%(\mathrm{w} / \mathrm{v})$ gentamicin (GibcoBRL, Gaithersburg, MD). Embryos were graded on the basis of morphology using a scale of 1 to 5 (Boland et al., 1978), washed twice with PBS containing $0.1 \%$ polyvinylalcohol (PVA), and then transferred, as pools of two or three embryos, in a minimal volume $(<1 \mu \mathrm{l})$ to the bottom of a $0.5 \mathrm{ml}$ tube. All embryo pools were lysed in $10 \mu \mathrm{l}$ GITC lysis buffer ( 4 mol guanidinium thiocyanate $1^{-1}, 0.1$ mol Tris $1^{-1}$ ( $\mathrm{pH} 7.4), 1$ mol beta-mercaptoethanol $\mathrm{1}^{-1}$ ). Samples were quick frozen in liquid nitrogen and transported on dry ice to the laboratory for analysis, where they were stored at $-70^{\circ} \mathrm{C}$. Only embryos from morphological grades 1 and 2 were used, and these were balanced across treatments. Details on embryo yields have been reported by Yaakub et al. (1999).

\section{Semi-quantitative RT-PCR}

Relative changes in the abundance of mRNA transcripts in embryo samples were determined using a semi-quantitative (SQ) RT-PCR assay, using exogenous added globin mRNA as an internal standard (Temeles et al., 1994). In this assay, the abundance of a given gene transcript in an embryo sample is determined by expressing the abundance of a gene-specific amplification product as a fraction of the $\alpha$-globin amplification product. This assay can be used to compare the relative abundance of one mRNA among different samples, but not the absolute amount of one mRNA compared with that of another (Temeles et al., 1994; Ho et al., 1994, 1995; Latham et al., 1995).

Since embryos isolated from heifers fed pulp- or barleybased diets were analysed in two different laboratories, using methods for measuring the relative abundance of mRNAs with minor differences, direct comparisons among diet types cannot be made and only general trends can be evaluated.

\section{Analysis of mRNA expression in embryos collected from heifers fed the pulp-based diets}

RNA isolation, RT-PCR, and quantification of amplification product on embryos from the pulp-based diets was performed as described by De Sousa et al. (1998a). At the time of thawing, $0.1 \mathrm{pg}$ rabbit globin RNA (Gibco-BRL, Burlington) were added per embryo equivalent, lysed in a sample and mixed by pipetting. For each sample, a $2 \mathrm{~mm} \times 2$ $\mathrm{mm}$ square of Hybond ${ }^{\mathrm{TM}}$-messenger affinity paper (mAP; Amersham International, Little Chalfont), wetted with 0.5 mol $\mathrm{NaCl} \mathrm{l}^{-1}$, was soaked in the lysed sample for 2-3 $\mathrm{h}$ at room temperature to allow for binding of poly $(\mathrm{A})^{+}$RNA. Unabsorbed lysates were pipetted onto respective mAP squares supported on Whatman 1 Filter paper (Whatman International Ltd, Springfield Mill) on parafilm. mAP squares were then transferred individually into separate 0.5 $\mathrm{ml}$ tubes and washed by gentle inversion with $200 \mu \mathrm{l}$ of 0.5 mol NaCl $1^{-1}, 0.1$ mol Tris $1^{-1}(3 \times), 0.5 \mathrm{~mol} \mathrm{NaCl} 1^{-1}(3 \times)$, and $70 \%$ ethanol (2x). Poly (A) $)^{+}$RNA was eluted from each $\mathrm{mAP}$ square in fresh tubes in $11 \mu \mathrm{l}$ sterile $\mathrm{H}_{2} \mathrm{O}$ containing $0.5 \mu \mathrm{g}$ oligo(dT) $)_{12-18}\left(\right.$ Gibco-BRL) by incubation at $70^{\circ} \mathrm{C}$ for $10 \mathrm{~min}$, followed by cooling on ice for $5 \mathrm{~min}$. RNA isolated by this procedure has been shown to be free of any contaminating genomic DNA (De Sousa et al., 1998a).

Reverse transcription reactions took place in a final volume of $20 \mu \mathrm{l}$ buffer, consisting of $50 \mathrm{mmol}$ Tris- $\mathrm{HCl} \mathrm{l}^{-1}$ ( $\mathrm{pH}$ 8.3), $75 \mathrm{mmol} \mathrm{KCl} \mathrm{l} \mathrm{m}^{-1}, 3 \mathrm{mmol} \mathrm{MgCl}_{2} \mathrm{l}^{-1}, 10 \mathrm{mmol}$ dithiothreitol $1^{-1}, \quad 750 \mu \mathrm{mol}$ dNTPs $1^{-1}$, and $300 \mathrm{iu}$ Superscript ${ }^{\mathrm{TM}}$ RNase $\mathrm{H}^{-}$(Gibco-BRL) for $90 \mathrm{~min}$ at $43^{\circ} \mathrm{C}$. Reactions were terminated at $5 \mathrm{~min}$ at $95^{\circ} \mathrm{C}$ and then placed on ice. Reverse transcribed cDNA was either used directly for PCR or stored at $-20^{\circ} \mathrm{C}$. As a negative control for RNA isolation and reverse transcription, a blank mAP square was carried along with the samples during the procedure.

Oligonucleotide primers for the amplification of $\mathrm{Na} / \mathrm{K}$ ATPase $\alpha 1, \mathrm{Cu} / \mathrm{Zn}$-SOD and $\alpha$-globin were designed using known sequence information (Table 1). PCRs were performed in $25 \mu \mathrm{l}$ of $1 \times$ GeneAmp PCR Buffer II $(10 \mathrm{mmol}$ Tris- $\mathrm{HCl} \mathrm{l^{-1 }}$, $\mathrm{pH} 8.3,50 \mathrm{mmol} \mathrm{KCl} \mathrm{l}^{-1}$; Perkin Elmer, Vaterstetten) containing $200 \mu \mathrm{mol} \mathrm{dNTPs}^{-1}, 2.5 \mathrm{iu}$ AmpliTaq

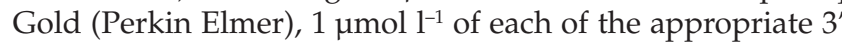
and $5^{\prime}$ gene specific primers, $1 \mathrm{mmol} \mathrm{MgCl}_{2} \mathrm{I}^{-1}(\mathrm{Na} / \mathrm{K}$ ATPase $\alpha 1$, and $\mathrm{Cu} / \mathrm{Zn}-\mathrm{SOD})$ or $1.25 \mathrm{mmol} \mathrm{MgCl}_{2} \mathrm{l}^{-1}(\alpha-$ globin), and a volume of the reverse transcription reaction corresponding to $0.1-0.2$ embryo equivalents. The basic programme for amplification of gene transcripts consisted of a $10 \mathrm{~min}$ soak at $94^{\circ} \mathrm{C}$, followed by a cycle programme of $1 \mathrm{~min}$ at $94^{\circ} \mathrm{C}$, a transcript-specific annealing temperature $(58,60$ and $55^{\circ} \mathrm{C}$, for $\mathrm{Na} / \mathrm{K}$-ATPase $\alpha 1, \mathrm{Cu} / \mathrm{Zn}$-SOD, and $\alpha$-globin, respectively) for $30 \mathrm{~s}$, and $1 \mathrm{~min}$ at $72^{\circ} \mathrm{C}$. The number of

Table 1. Primers used for RT-PCR and the size of diagnostic amplification products

\begin{tabular}{lllc}
\hline Gene primers $^{\mathrm{a}}$ & & Primer sequence & Product size (bp) \\
\hline $\mathrm{Na} /$ K-ATPase $\alpha 1$ & $5^{\prime}$ & $5^{\prime}$-ACCTGTTGGGCATCCGAGAGAC-3' & 336 \\
$\mathrm{Cu} /$ Zn-SOD & $3^{\prime}$ & $5^{\prime}$-AGGGGAAGGCACAGAACCACCA-3' & \multirow{2}{*}{246} \\
$\alpha$-globin & $5^{\prime}$ & $5^{\prime}$-AAGGCCGTGTGCGTGCTGAA-3' & 257 \\
& $3^{\prime}$ & $5^{\prime}$-CAGGTCTCCAACATGCCTCT-3' & \\
& $5^{\prime}$ & $5^{\prime}$-GCAGCCACGGTGGCGAGTAT-3' & \\
& $3^{\prime}$ & $5^{\prime}$-GTGGGACAGGAGCTTGAAAT-3' &
\end{tabular}

${ }^{a} \mathrm{Na} /$ K-ATPase $\alpha 1$ primers were based on regions of shared homology between the rat and horse sequences (Shull et al., 1986; Kano et al., 1989) and amplified a product from bovine cDNA that was $90.1 \%$ identical to the corresponding cDNA sequence in rats (Betts et al., 1997). Cu/Zn-SOD primers were based on the rat sequence (Ho and Crapo, 1987), and have been shown to amplify a product of the correct size, with the anticipated diagnostic restriction enzyme site, from bovine cDNA (Harvey et al., 1995). For $\alpha$-globin, the 5' and 3' primers correspond to bp 241-260 and 555-657, respectively, in the rabbit $\alpha$-globin genomic clone (Cheng et al., 1986). 
cycles were 35 (Na/K-ATPase $\alpha 1), 38$ (Cu/Zn-SOD), and 31 ( $\alpha$-globin).

RT-PCR products were visualized by separation for 45 min at $100 \mathrm{~V}$ on $2 \%$ agarose gels in $1 \times$ TAE buffer $(40 \mathrm{mmol}$ Tris-acetate $1^{-1}, 1 \mathrm{mmol}$ EDTA ${ }^{-1}$ ) containing $0.5 \mu \mathrm{g} \mathrm{ml}^{-1}$ ethidium bromide. RT-PCR products were quantified by capillary electrophoresis (De Sousa et al., 1998a), using a Beckman P/ACE System 2100 in conjunction with a laserinduced fluorescence (LIF) detector operating with an argon ion $488 \mathrm{~nm}$ laser and a $530 \mathrm{~nm}$ emission filter.

\section{Analysis of $m R N A$ expression in embryos collected from heifers fed the barley-based diets}

Poly(A)+RNA was isolated using a Dynabeads mRNA DIRECT Kit (Dynal ${ }^{\circledR}$, Oslo) according to the manufacturer's instructions, with minor modifications as described by Wrenzycki et al. (1998b, 1999). Briefly, embryos were lysed by adding $150 \mu \mathrm{l}$ lysis-binding buffer $\left(100 \mathrm{mmol}\right.$ Tris- $\mathrm{HCl} \mathrm{l}^{-1}$, pH 8.0, $500 \mathrm{mmol} \mathrm{LiCl} \mathrm{l}^{-1}, 10$ mmol EDTA 1-1, 1\% (w/v) LiDS (SDS), $5 \mathrm{mmol}$ dithiothreitol $\left.\mathrm{l}^{-1}\right)$. Rabbit globin mRNA (0.1 pg; BRL, Gaithersburg, MD) per oocyte or embryo was added to each tube as an internal standard. After vortexing for $10 \mathrm{~s}$, brief centrifugation at $12000 \mathrm{~g}$ for $5 \mathrm{~s}$ and incubation at room temperature for $10 \mathrm{~min}, 10 \mu \mathrm{l}$ prewashed Dynabeads ${ }^{\circledR}$ Oligo $(\mathrm{dT})_{25}$ was pipetted into the fluid. After 5 min incubation at room temperature for binding poly $(\mathrm{A})^{+}$RNAs to oligo (dT) Dynabeads, the beads were separated employing a Dynal MPC-E-1 magnetic separator, washed once using $100 \mu \mathrm{l}$ washing buffer 1 (10 mmol Tris- $\mathrm{HCl} \mathrm{l}^{-1}$, pH 8.0, 0,15 mol LiCl l-1, 1 mmol EDTA 1 ${ }^{-1}, 0,1 \%$ $(\mathrm{w} / \mathrm{v}) \mathrm{LiDS}$ ) and three times with $100 \mu \mathrm{l}$ washing buffer 2 (10 mmol Tris- $\mathrm{HCl}$, pH 8.0, 0,15 mol LiCl l-1, $1 \mathrm{mmol} \mathrm{EDTA}^{-1}$ ). Poly $(\mathrm{A})^{+}$RNAs were then eluted from the beads by incubation in $11 \mu \mathrm{l}$ sterile water at $65^{\circ} \mathrm{C}$ for $2 \mathrm{~min}$, and aliquots were used immediately for reverse transcription.

Poly $(\mathrm{A})^{+}$RNA was reverse transcribed into cDNA in a total volume of $20 \mu \mathrm{l}$, using $2.5 \mu \mathrm{mol}$ random hexamers $\mathrm{I}^{-1}$ (Perkin-Elmer) to get the widest array of cDNAs. The reaction mixture consisted of $1 \times \mathrm{RT}$ buffer $\left(50 \mathrm{mmol} \mathrm{KCl} \mathrm{l}^{-1}\right.$, 10 mmol Tris- $\mathrm{HCl} \mathrm{l}^{-1}, \mathrm{pH}$ 8.3, Perkin-Elmer, Vaterstetten), 5 mmol $\mathrm{MgCl}_{2} \mathrm{l}^{-1}, 1 \mathrm{mmol} \mathrm{1^{-1 }}$ of each dNTP (Amersham, Brunswick), 20 iu RNase inhibitor (Perkin-Elmer) and 50 iu MuLV reverse transcriptase (Perkin-Elmer). The mixture was overlaid with mineral oil to prevent evaporation. The RT reaction was carried out at $25^{\circ} \mathrm{C}$ for $10 \mathrm{~min}, 42^{\circ} \mathrm{C}$ for $1 \mathrm{~h}$, followed by a denaturation step at $99^{\circ} \mathrm{C}$ for $5 \mathrm{~min}$ and flash cooling on ice.

PCR was performed with a volume of the RT reaction corresponding to 0.1 or 0.2 embryo equivalents and a volume of the RT reaction corresponding to $10 \mathrm{fg}$ equivalent of globin RNA in a final volume of $50 \mu$ consisting of $1 \times$ PCR buffer (20 mmol Tris- $\mathrm{HCl} \mathrm{l}^{-1}$, pH 8.4, $50 \mathrm{mmol} \mathrm{KCl} \mathrm{l}^{-1}$, Gibco BRL, Eggenstein), $1.5 \mathrm{mmol} \mathrm{MgCl}_{2} \mathrm{l}^{-1}, 200 \mathrm{mmol} \mathrm{l}^{-1}$ of each dNTP, $1 \mu \mathrm{mol} \mathrm{l}^{-1}$ of each sequence specific primer (globin: $0.5 \mu \mathrm{mol}$ $1^{-1}$ ) using a PTC-200 thermocycler (MJ Research, Watertown, MA). A 'hot start' PCR was performed to obtain specific amplification. During the hot start, $1 \mathrm{iu}$ Taq DNA polymerase (Gibco, Paisley) was added at $72^{\circ} \mathrm{C}$. The sequences and positions of the primers used, the fragment sizes and the sequence references of the expected PCR products are summarized (Table 1).

The PCR program used an initial step at $99^{\circ} \mathrm{C}$ for $5 \mathrm{~min}$ and $72^{\circ} \mathrm{C}$ for $2 \mathrm{~min}$ (hot start) followed by 28 cycles (globin: 30 cycles) of $15 \mathrm{~s}$, each at $95^{\circ} \mathrm{C}$ for DNA denaturation, $15 \mathrm{~s}$ at different temperatures for annealing of primers, and $15 \mathrm{~s}$ at $72{ }^{\circ} \mathrm{C}$ for primer extension. The last cycle was followed by a 5 min extension at $72^{\circ} \mathrm{C}$ and cooling to $4^{\circ} \mathrm{C}$.

Generation of the diagnostic fragments was strictly dependent on the presence of RNA in the RT reaction, since omitting reverse transcriptase from the RT did not generate any amplified fragments (data not shown).

After addition of $5 \mu \mathrm{l}$ of $10 \times$ loading buffer $(0.25 \%(\mathrm{w} / \mathrm{v})$

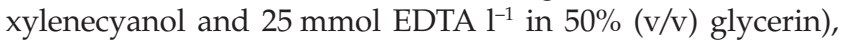
$10 \mu \mathrm{l}$ of the RT-PCR products were subjected to electrophoresis on a $2 \%$ agarose gel in $1 \times$ TBE buffer (90

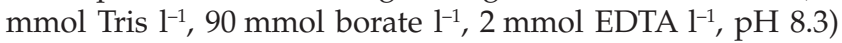
containing $0.2 \mu$ g ethidium bromide $(\mathrm{EtBr}) \mathrm{ml}^{-1}$ with a further addition of in the same concentration as in the running buffer. After running at $80 \mathrm{~V}$ for $45 \mathrm{~min}$, the fragments were visualized on an $312 \mathrm{~nm}$ UV-transilluminator. The image of each gel was digitized using a CCD camera (Quantix, Photometrics, München) and the IP Lab spectrum (IP Lab Gel, Signal Analytics Corporation, Vienna, VA). The signal intensity of each band was quantitated by densitometric scanning using a computer-assisted image analysis system (IP Lab Gel). The relative amount of the mRNA of interest was calculated by dividing the intensity of the band for each developmental stage by the intensity of the globin band for the corresponding stage. For each mRNA, experiments were repeated with at least three separate embryo batches.

\section{Measurement of $\left[{ }^{14} \mathrm{C}\right]$ pyruvate metabolism by individual embryos produced in vivo}

Radiolabelled pyruvate $\left(\left[2{ }^{14} \mathrm{C}\right], \quad 15.4 \mathrm{mCi} \mathrm{mmol}^{-1}\right.$; Dupont-NEN, Brussels) was reconstituted in CR1aa-Hepes medium (Rosenkrans and First, 1994) to a stock concentration of $0.05 \mu \mathrm{Ci} \mu \mathrm{l}^{-1}$, and sodium bicarbonate $\left(\left[{ }^{14} \mathrm{C}\right]\right.$, $0.1 \mathrm{mCi} \mathrm{mmol}^{-1}$; Amersham International) was used at the concentration of $0.25 \mu \mathrm{Ci} \mu \mathrm{l}^{-1}$. Labelled reagents were stored at $4^{\circ} \mathrm{C}$. The radiometric, hanging-drop method of Rieger et al. (1992a) was used to measure pyruvate metabolism. Individual embryos from each nutrition treatment were taken up in $2 \mu \mathrm{l}$ of CR1aa-Hepes medium and transferred to the cap of a sterile $2.5 \mathrm{ml}$ screw-cap mini-vial (Sarstedt, Newton, NC). Immediately, $2 \mu \mathrm{l} \mathrm{CR1aa-Hepes,} \mathrm{containing}$ $\left[2-{ }^{14} \mathrm{C}\right]$ pyruvate was added, resulting in a total culture volume of $4 \mu \mathrm{l}$, and the cap was carefully secured onto the 2.5 $\mathrm{ml}$ mini-vial. Each mini-vial contained $1.75 \mathrm{ml}$ of $25 \mathrm{mmol}$ $\mathrm{NaHCO}_{3} 1^{-1}$ that had been equilibrated for $2 \mathrm{~h}$ to a humidified atmosphere of $5 \% \mathrm{CO}_{2}$ in air at $39^{\circ} \mathrm{C}$. Assay control mini-vials included sham preparations $(n=5)$ that contained all reagents but did not include an embryo (to account for nonspecific counts), and background mini-vials containing $2 \mu 1$ unlabelled CR1aa medium. Embryos were cultured for $3 \mathrm{~h}$ $\left(39^{\circ} \mathrm{C}\right)$. The caps were removed, and the bicarbonate contained within the vial quickly poured into a $20 \mathrm{ml}$ 
scintillation vial containing $0.2 \mathrm{ml}$ of $0.1 \mathrm{~mol} \mathrm{NaOH} \mathrm{l}^{-1}$ and capped. The scintillation vials were gently mixed and held at $4^{\circ} \mathrm{C}$ overnight to facilitate conversion of dissolved $\left[{ }^{14} \mathrm{C}\right] \mathrm{O}_{2}$ and bicarbonate into carbonate. Scintillation fluid was added $(15 \mathrm{ml})$, and disintegrations per minute (d.p.m.) determined by counting for 5 min using a Packard Tri-Carb scintillation counter programmed for automatic-quench correction. Two microlitres of labelled $\left[{ }^{14} \mathrm{C}\right]$ pyruvate were mixed with $1.75 \mathrm{ml}$ $\mathrm{NaHCO}_{3}$ and $0.2 \mathrm{ml} \mathrm{NaOH}$, and the radioactivity quantified in the same manner, to determine total substrate d.p.m. The amount of $\left[{ }^{14} \mathrm{C}\right]$ pyruvate metabolized by individual embryos was calculated as described by Tiffin et al. (1991) and Rieger et al. (1992a,b). The mean d.p.m. for the sham preparations was subtracted from the d.p.m. value of each embryo, and the difference divided by the total $\left[{ }^{14} \mathrm{C}\right]$ pyruvate d.p.m. and multiplied by the total quantity of substrate (labelled and unlabelled pyruvate) in $4 \mu \mathrm{l}$ medium. This value was then multiplied by the product recovery correction factor of 1.04 (100/96.1) determined for the $3 \mathrm{~h}$ culture period (Rieger et al., 1992a). This calculation involved generating a standard percentage recovery curve over the $3 \mathrm{~h}$ incubation period to determine the plateau saturation value of $\mathrm{NaH}\left[{ }^{14} \mathrm{C}\right] \mathrm{O}_{3}$ at $3 \mathrm{~h}$ (data not shown).

\section{Statistical analysis}

Expression data were analysed using the SigmaStat 2.0 (Jandel Scientific, San Rafael, CA) software package. Parametric analysis of differences in the means between two or more populations were tested using ANOVA with the main effects of day of collection and quantity of diet and their interactions followed by multiple pairwise comparisons using a Tukey's test. Pyruvate uptake data were analysed by the SAS software package, version 6.0 (SAS Institute Inc., 1989) using the generalized linear models (GLM) procedure, with the main effects of day of collection, quantity of diet and type of diet and their interactions. Differences of $P \leq 0.05$ were considered to be significant.

As the relative abundances of specific mRNAs in embryos from animals fed either the pulp- or barley-based diets were determined in two different laboratories, no comparisons can be made between these groups. However, pyruvate use was measured from both embryo types in the same lab, allowing comparisons among all groups.

Correlations between the relative abundance of each mRNA of embryos recovered from heifers fed the different diets and the corresponding pyruvate metabolism data were calculated with the Pearson product moment correlation.

\section{Results}

Superovulatory response (number of corpora lutea at slaughter) was greater $(P<0.06)$ when heifers were offered 3 $\mathrm{kg}$ per day $(15.5 \pm 1.6)$ than when they were offered ad libitum concentrates $(12.3 \pm 1.4)$. The superovulatory response for both citrus-beet pulp $(14.4 \pm 1.5)$ and barley $(13.3 \pm 1.5)$ was not different $(P>0.05)$. Heifers offered $3 \mathrm{~kg}$ concentrates per day produced greater numbers of transferable embryos (4.8 $\pm 0.07)$ compared with heifers offered ad libitum concentrates $(2.8 \pm 0.8 ; \quad P<0.05)$. Heifers offered citrus-beet pulp produced greater numbers of transferable embryos $(4.8 \pm$ $0.07)$ than heifers offered barley $(2.9 \pm 0.05 ; P<0.05)$. Details have been reported by Yaakub et al. (1999).

\section{Relative abundance of $\mathrm{Na} / \mathrm{K}-\mathrm{ATP}$ ase $\alpha \mathrm{I}$ and $\mathrm{Cu} / \mathrm{Zn}$-SOD transcripts in embryos}

For all primer pairs, the number of PCR cycles was kept within the linear range of amplification (De Sousa et al., 1998b; Wrenzycki et al., 1999). Globin RNA, added before RNA isolation as an internal standard, was effectively amplified at 30-31 PCR cycles (Fig. 1a), showing a linear increase in the amount of PCR products as a function of RNA input up to $160 \mathrm{fg}$ (Fig. 1b).

Transcripts for Na/K-ATPase $\alpha 1, \mathrm{Cu} / \mathrm{Zn}-\mathrm{SOD}$, and exogenously supplied $\alpha$-globin were amplified from bovine embryos developed in vivo from heifers on $3 \mathrm{~kg}$ per day or ad libitum diets of citrus-beet pulp or barley are shown (Fig. $2 a, b)$. In embryos derived from heifers fed the pulp-based diets, the relative abundances of both transcripts were not affected by either day of collection or quantity of diet (Fig. 3a). In embryos derived from heifers fed the barley-based diets, the relative abundances of the $\mathrm{Na} / \mathrm{K}$-ATPase transcripts were also not changed by these main effects, while the relative abundances of the $\mathrm{Cu} / \mathrm{Zn}$-SOD transcripts were affected by day of collection (significantly lower in day 6 than in day 7 embryos) and by the quantity of diet (Fig. 3b). No interactive effects were observed for day of collection and quantity of diets in the relative abundance of both transcripts.

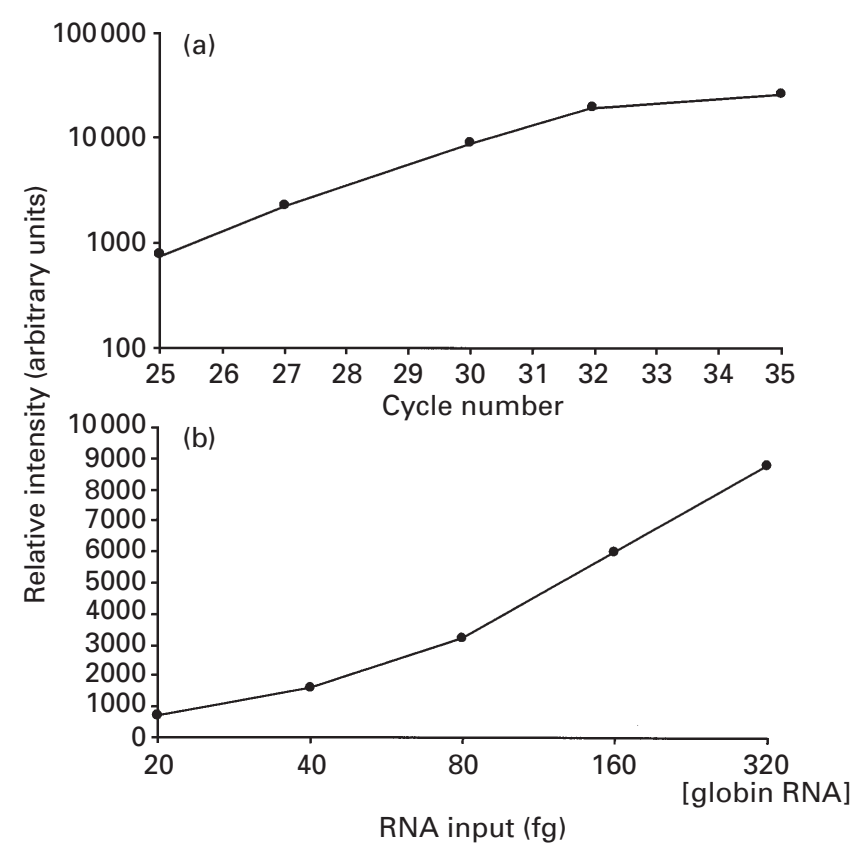

Fig. 1. Validation of the semi-quantitative RT-PCR assay in terms of the number of cycles using an amount of $20 \mathrm{fg}$ globin RNA (a) or different amounts of globin RNA using 30 PCR cycles (b). 

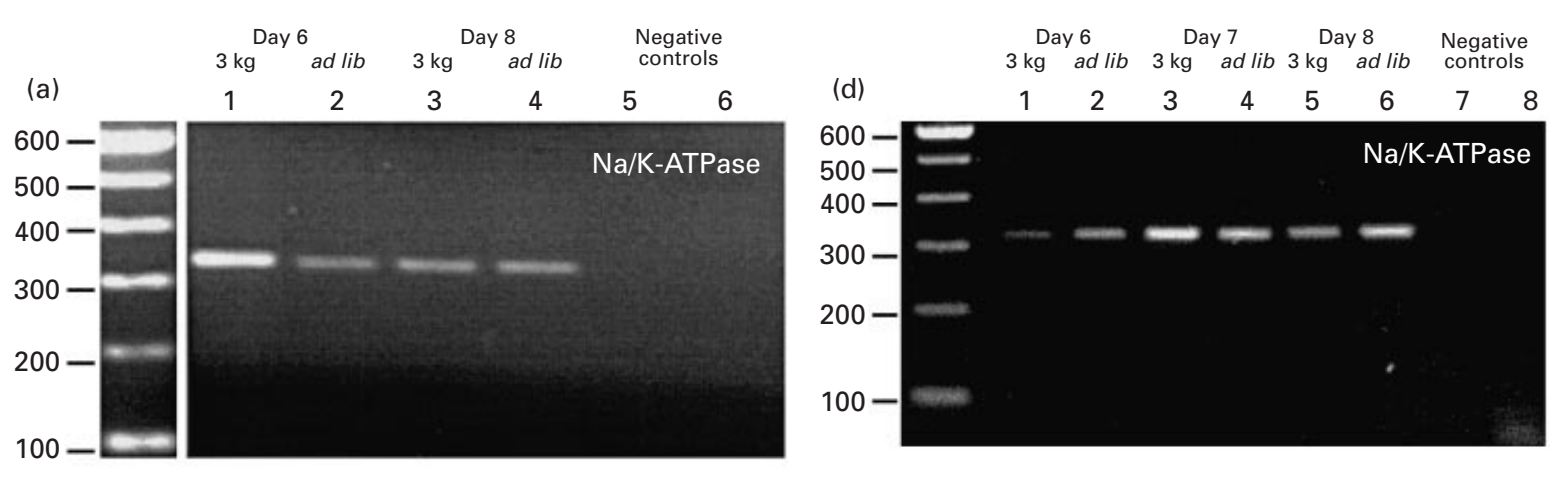

(b)
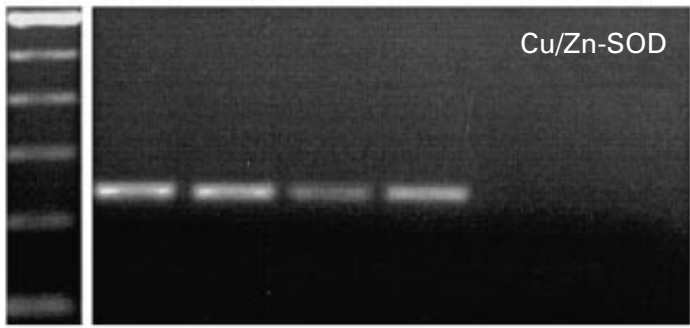

(c)

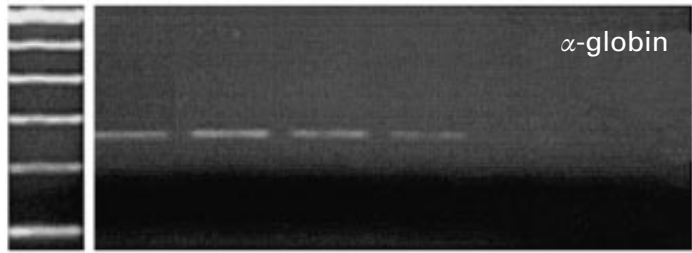

(e)

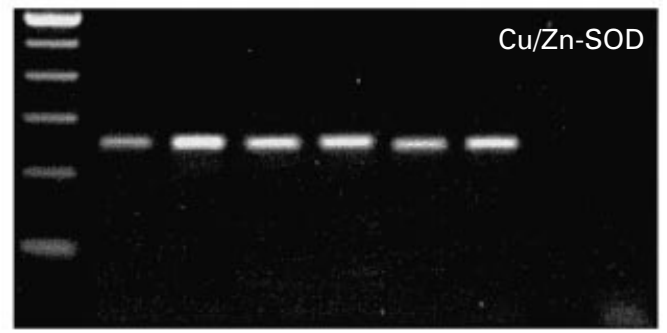

(f)

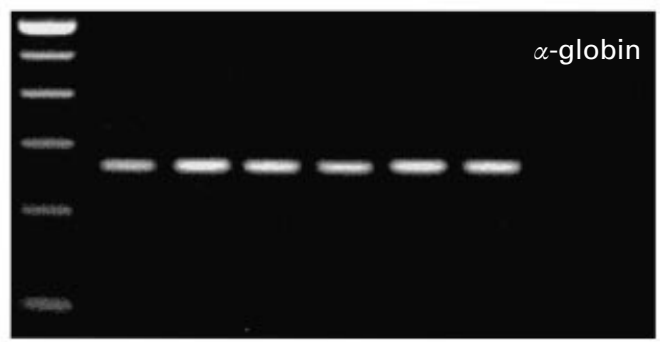

Fig. 2. Detection of genetranscripts in bovine morulae and blastocysts developed in vivo from heifers on $3 \mathrm{~kg}$ per day or ad libitum daily intakes of citrus-beet pulp $(\mathrm{a}-\mathrm{c})$ or barley $(\mathrm{d}-\mathrm{f})$. Representative ethidium bromide-stained gels showing amplification of a $336 \mathrm{bp}$ product representing $\mathrm{Na} / \mathrm{K}-\mathrm{ATPase} \alpha 1$ transcript $(\mathrm{a}, \mathrm{d})$, a $246 \mathrm{bp}$ product representing the $\mathrm{Cu} / \mathrm{Zn}-\mathrm{SOD}$ transcript $(\mathrm{b}, \mathrm{e})$, and a $257 \mathrm{bp}$ product representing the exogenously supplied $\alpha$-globin transcript $(\mathrm{c}, \mathrm{f})$, amplified from day 6 (lanes 1 and 2), day 7 (d-f, lanes 3 and 4 ) and day 8 (a-c, lanes 3 and 4 ; $d-f$, lanes 5 and 6) from heifers on $3 \mathrm{~kg}$ per day (a-c, lanes 1 and 3 ; d-f, lanes 1,3 and 5) or ad libitum (a-c, lanes 2 and 4; d-f, lanes 2, 4 and 6 ) diets. As negative controls, transcript-specific PCR was performed on aliquots of mock reverse transcriptions on blank mAP squares run through the RNA isolation procedure (a-c: lane 5) and water (a-c: lane 6), while RNA (d-f: lane 7) or reverse transcriptase (d-f: lane 8) was omitted during the RT reaction. ad lib: ad libitum.

\section{$\left[{ }^{14} \mathrm{C}\right]$ pyruvate metabolism by individual bovine embryos}

The effects of day of collection (Fig. 4a), quantity of diets (Fig. 4b), and type of diets (Fig. 4c) on the utilization of [2${ }^{14}$ C]pyruvate by bovine embryos produced in vivo is shown. Pyruvate metabolism was affected by day of collection and showed a significant increase in day 8 embryos compared with day 7 and day 6 embryos. Diet quantity did not affect pyruvate utilization, whereas pyruvate metabolism was significantly increased in the barley diet group compared with the pulp diet group. No interactive effects were observed for day of collection, quantity of diets and type of diets in pyruvate metabolism.

The relative abundances of the $\mathrm{Cu} / \mathrm{Zn}$-SOD transcript and pyruvate metabolism showed a negative significant correlation $(r=-0.84, P \leq 0.05)$ in embryos collected from heifers fed barley diets.

\section{Discussion}

The present study is the first to investigate the effects of quantity and type of diet on mRNA expression and energy metabolism in preimplantation bovine embryos. Alterations in the relative amounts of specific gene transcripts in bovine oocytes produced in vitro and embryos during preimplantation development have been determined using a sensitive semi-quantitative RT-PCR assay (Lequarre et al., 1997; De Sousa et al., 1998a; Wrenzycki et al., 1999). Furthermore, this technique has been used to determine the effects of different culture conditions on the amount of mRNA expression of various developmentally important genes (Wrenzycki et al., 1998b, 1999). Variations in the detected amounts of different mRNAs may be attributed to the mRNA structure or the intracellular environment affecting the stability and turnover rate of the mRNA (Ross, 

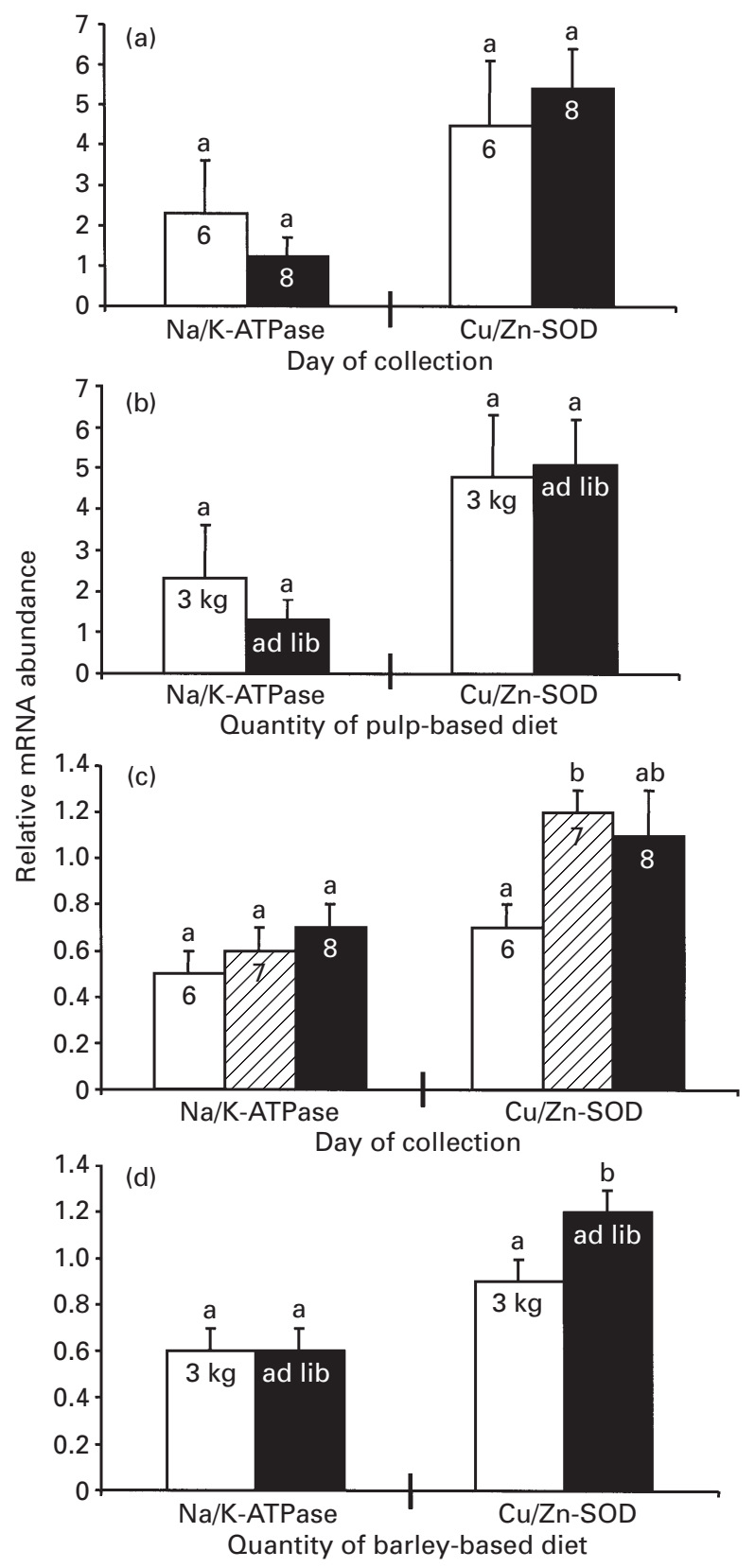

Fig. 3. Variations in the relative abundance of mRNA in bovine morulae and blastocysts developed in heifers on diets of citrus-beet pulp $(\mathrm{a}, \mathrm{b})$ or barley $(\mathrm{c}, \mathrm{d})$ affected by day of collection $(\mathrm{a}, \mathrm{c})$ or quantity of diets $(b, d)$. The mean relative mRNA abundance ( \pm SEM) was determined for $\mathrm{Na} / \mathrm{K}$-ATPase $\alpha 1$, and $\mathrm{Cu} / \mathrm{Zn}$-SOD from embryos in three independent RNA isolation RT-PCR experiments. Significant differences are denoted by different superscripts $(P \leq 0.05)$. ad lib: ad libitum.

1996) as well as the methodology used to detect rare transcripts. Polyadenylation may increase the presence of a messenger after reverse transcription with an oligo-dT primer by increasing the probability that such a primer will anneal to the transcript (Moore et al., 1996; De Sousa et al.,

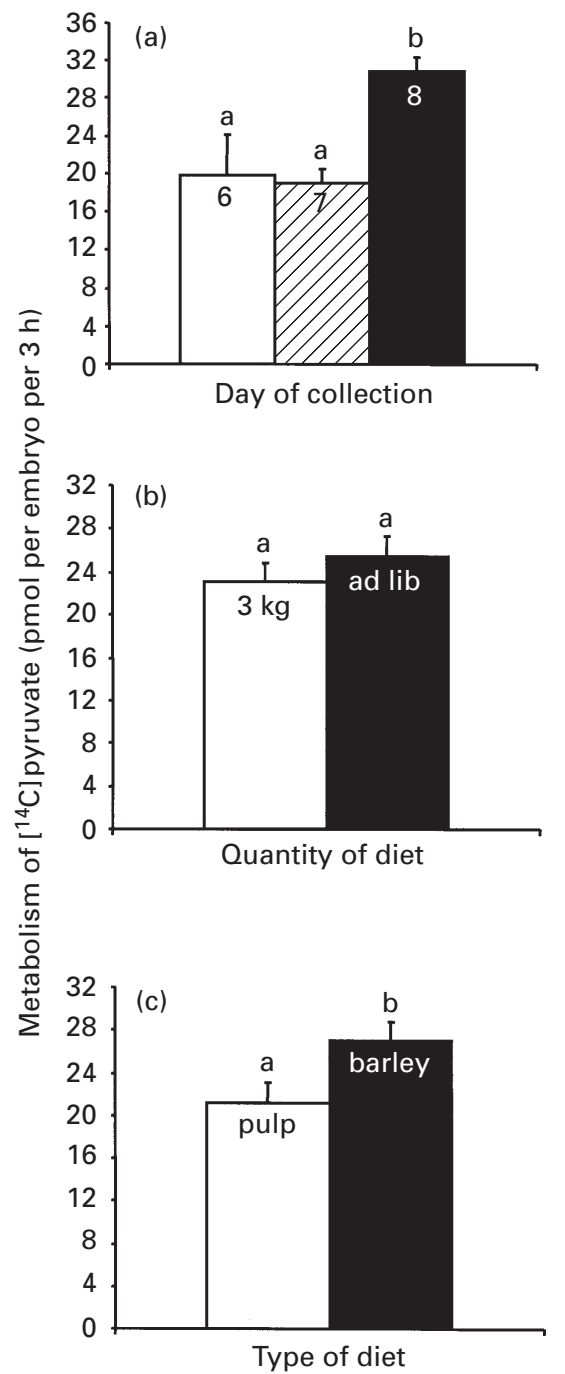

Fig. 4. Pyruvate metabolism by individual embryos produced in vivo from heifers on diets of citrus-beet pulp and barley affected by (a) day of collection, (b) quantity of diets or (c) type of diet.

1998b). However, the increase of most gene transcripts results from synthesis de novo after the major activation of the bovine embryonic genome at the 8-16-cell stage (Telford et al., 1990). Despite analysis by independent laboratories with slight modifications in methodology in the present study, the differences tend to be similar within the experimental subgroups.

During preimplantation development, the formation of the blastocyst is mediated by fluid transfer across the outer blastomeres through the activity of $\mathrm{Na} / \mathrm{K}$-ATPase. $\mathrm{Na} / \mathrm{K}$ ATPase is composed of two subunits, of which the $\alpha$ (catalytic) subunit represents the physiological role of the enzyme (Jorgensen, 1986), while the $\beta$ (noncatalytic, glycolysated) subunit is thought to facilitate the processing and insertion of the $\alpha$ subunit into the plasma membrane (Geering, 1991). The functional expression of the $\alpha$ subunit is regulated after transcription during preimplantation 
development (Kidder, 1992). As no differences in the relative abundance of the $\alpha 1$ transcripts were found in embryos from all treatment groups, this transcript seems to possess an enormous plasticity to various environments, or acts rather independent from environmental factors.

Free oxygen radicals (FOR) have been implicated in embryonic arrest and cell death (Johnson and Nasr-Esfahani, 1994). FOR production is a physiological process that occurs within cells when electrons leak to oxygen during electron transfer reactions. This has pronounced effects on DNA, RNA and protein synthesis, and pertubates cell membranes, increases intracellular $\mathrm{pH}$ and disturbs mitochondrial function. While there are numerous non-enzymatic antioxidant agents, specific antioxidant enzymes are able to detoxify $\mathrm{O}_{2}^{-}, \mathrm{H}_{2} \mathrm{O}_{2}$, and organic peroxides (Johnson and Nasr-Esfahani, 1994), that is, $\mathrm{Cu} / \mathrm{Zn}$-SOD catalyses the dismutation reaction, removing $\mathrm{O}_{2}$ species. The significant increase of $\mathrm{Cu} / \mathrm{Zn}$-SOD transcripts recovered from heifers fed barley-based diets, either ad libitum or restricted, may be caused by oxidative stress as a result of ad libitum feeding of the donor animals. In addition, it has been proposed that heat shock proteins, such as HSP 70, are induced by FOR (Donati et al., 1990). The transcription of this gene is induced by suboptimal culture conditions in mouse embryos (Christians et al., 1995) and bovine preimplantation embryos (Wrenzycki et al., 1998b, 1999). The differences between embryos collected on different developmental days may be attributed to varying cell numbers.

Evidence indicates that the rate of energy substrate utilization by preimplantation embryos is an appropriate predictive parameter for embryo viability (Rieger, 1984; Gardner and Leese, 1986, 1988; Rondeau et al., 1995). Radiolabelled energy substrates have been used extensively in studies of bovine embryo metabolism (Rieger, 1984, 1992; Rieger and Guay, 1988; Javed and Wright, 1991; Tiffin et al., 1991; Rieger et al., 1992a, b). Furthermore, peroxidative damage of mitochondrial lipids results in a shift in the cells from oxidative use of pyruvate in the Krebs cycle to metabolize succinate (Johnson and Nasr-Esfahani, 1994).

The effects of nutrition on preimplantation embryo development may reflect the general energy balance, while other effects may be attributed to those of specific nutrients, such as vitamins or minerals. When defining nutritional effects, the response to nutrition at one stage of the reproductive cycle may have profound responses at a later stage. Effects on the preovulatory development of the oocyte will carry over into the periovulatory period (Downing et al., 1995; Thomas et al., 1997) and these nutritional effects could continue to affect pre- and post-fertilization events within the oviduct (Rabiee et al., 1997). The uterine phase of development is affected by nutritional factors either indirectly, by effects on progesterone secretion, or directly at the uterus. In sheep, effects on circulating progesterone concentrations may be an important mechanism by which nutrition and metabolic state alter embryo survival (Parr et al., 1987, 1993). Furthermore, in superovulated ewes infused with glucose, a decrease in ovulation rate and embryo quality was found (Yaakub et al., 1997).

The correlation data demonstrate that feeding the barleybased diet ad libitum to the donor heifers led to a decreased pyruvate utilization and an increase in the relative abundance of the $\mathrm{Cu} / \mathrm{Zn}$-SOD transcript in day 8 embryos. The correlation indicates that the increased amounts of $\mathrm{Cu} / \mathrm{Zn}-\mathrm{SOD}$ mRNA are due to cellular stress in these embryos. This hypothesis is supported by the fact that, in embryos derived from heifers fed barley-based diets, pyruvate uptake is significantly increased compared with that in embryos from heifers fed pulp-based diets. Reduced development of bovine embryos grown in vitro under serumfree conditions is also associated with increased pyruvate uptake (Eckert et al., 1999). Furthermore, a significantly smaller number of transferable embryos was recovered from barley-fed compared with pulp-fed donor animals (Yaakub et al., 1999) indicating that there is a negative association between the barley diet and early embryonic development. In addition, oxidative stress caused by ad libitum feeding of the donor animals may also lead to a significantly decreased number of transferable embryos compared with donor animals fed restricted diets (Yaakub et al., 1999).

In conclusion, for the first time, differences in gene expression and metabolic substrate metabolism in in vivo derived embryos collected from heifers fed different quantities and types of diet were determined. These differences observed in embryos collected on the same day of development can be attributed to the composition and quantity of diet fed to the donor animal. The type of diet may also alter oocyte development and maturation and embryonic development by alteration of the microenvironment. As a result of these metabolic changes, transcription and translation of key developmental genes may be altered with effects on early development. The present findings characterize embryos produced in vivo at the molecular level, and indicate that these molecular markers can be used to differentiate between populations of embryos produced under different nutritional regimens, and to determine conditions conducive to the production of good quality embryos.

\section{References}

Armstrong DT (1993) Recent advances in superovulation in cattle Theriogenology 397-24

Betts DH, MacPhee DJ, Kidder GM and Watson AJ (1997) Ouabain sensitivity and expression of $\mathrm{Na} / \mathrm{K}$-ATPase $\alpha$ - and $\beta$-subunit isoform genes during bovine early development Molecular Reproduction and Development 46 114-126

Blanchard T, Ferguson J, Love L, Takeda T, Henderson B, Hasler J and Chalupa W (1990) Effect of dietary crude-protein type on fertilization and embryo quality in dairy cattle American Journal of Veterinary Research 51 905-908

Boland MP, Crosby TF and Gordon I (1978) Morphological normality of cattle embryos following superovulation using PMSG Theriogenology 36 169-183

Boland MP, Goulding D and Roche JF (1991) Alternative gonadotropins for superovulation in cattle Theriogenology 35 5-17

Bungartz L and Niemann H (1994) Assessment of the presence of a dominant follicle and selection of dairy cows suitable for superovulation by a single ultrasound examination Journal of Reproduction and Fertility 101 583-591

Cheng J-F, Raid L and Hardison RC (1986) Isolation and nucleotide sequence of rabbit globin gene cluster $\psi \zeta$ - $\alpha 1-\alpha \psi$. Absence of a pair of $\alpha$-globin genes evolving in concert Journal of Biological Chemistry 261 839-848

Christians E, CampionE, Thompson EM and Renard J-P (1995) Expression of the HSP 70.1 gene, a landmark in early zygotic activity in the mouse embryo is restricted to the first burst of transcription Development 121 113-122 
De Sousa PA, Westhusin ME and Watson AJ (1998a) Analysis of variation in relative mRNA abundance for specific gene transcripts in single bovine oocytes and early embryos Molecular Reproduction and Development 49 119-130

De Sousa PA, Watson AJ and Schultz RM (1998b) Transient expression of a translation initiation factor is conservatively associated with embryonic gene activation in murine and bovine embryos Biology of Reproduction 59 969-977

Donati YRA, Slosman DO and Polla BS (1990) Oxidative injury and the heat shock response Biochemical Pharmacology 40 2571-2577

Downing JA and Scaramuzzi RJ (1991) Nutrient effects on ovulation rate, ovarian function and the secretion of gonadotrophin and metabolic hormones in sheep Journal of Reproduction and Fertility Supplement 43 209-227

Downing JA, Joss J and Scaramuzzi RJ (1995) Ovulation rate and the concentrations of gonadotrophins and metabolic hormones in ewes infused with glucose during the late luteal phase of the oestrus cycle Journal of Endocrinology 146 403-410

Eckert J, Pugh PA, Thompson JG, Niemann H and Tervit R (1998) Exogenous protein affects developmental competence and metabolic activity of bovine preimplantation embryos in vitro. Reproduction, Fertility and Development $\mathbf{1 0}$ 327-332

Gardner DK (1998) Changes in requirements and utilization of nutrients during mammalian preimplantation embryo development and their significance in embryo culture Theriogenology 49 83-102

Gardner DK and Leese HJ (1986) Non-invasive measurement of nutrient uptake by single cultured preimplantation mouse embryos Human Reproduction 125-27

Gardner DK and Leese HJ (1988) The role of glucose and pyruvate transport in regulating nutrient utilization by preimplantation mouse embryos Development 104 423-429

Geering K (1991) The functional role of the beta subunit in the maturation and intracellular transport of Na/K-ATPase FEBS Letters 285 189-193

Goulding D, Williams DH, Roche JF and Boland MP (1994) Effect of exogenous progesterone on superovulatory response in heifers inseminated with fresh or frozen semen Journal of Reproduction and Fertility 100 505-510

Goulding D, Williams DH, Roche JF and Boland MP (1996) Factors affecting superovulation in heifers treated with PMSG Theriogenology 45 765-773

Harvey MB, Arcellana-Panlilio MY, Zhang X, Schultz GA and Watson AJ (1995) Expression of genes encoding antioxidant enzymes in preimplantation mouse and cow embryos and primary bovine oviduct cultures employed for embryo coculture Biology of Reproduction 53 532-540

Ho Y, Doherty AS and Schultz RM (1994) Mouse preimplantation embryo development in vitro: effect of sodium concentration in culture media on RNA synthesis and accumulation and gene expression Molecular Reproduction and Development 38 131-141

Ho Y, Wigglesworth K, Eppig JJ and Schultz RM (1995) Preimplantation development of mouse embryos in KSOM: augmentation by amino acids and analysis of gene expression Molecular Reproduction and Development $\mathbf{4 1}$ 232-238

Ho YS and Crapo JD (1987) Sequences of cDNA and deduced amino acid of rat copper-zinc-containing superoxide dismutase Journal of Biological Chemistry 265 1588-1593

Javed MH and Wright RW, Jr (1991) Determination of pentose phosphate and Embden-Meyerhof pathway activities in bovine embryos Theriogenology 35 1029-1037

Johnson MH and Nasr-Esfahani MH (1994) Radical solutions and cultural problems: could free oxygen radicals be responsible for the impaired development of preimplantation mammalian embryos in vitro? BioEssays 16 31-38

Jorgensen PL (1986) Structure, function and regulation of the $\mathrm{Na} / \mathrm{K}$-ATPase in the kidney Kidney International 29 10-20

Kano I, Nagai F, Satoh K, Ushiyama K, Nakao T and Kano K (1989) Structure of the $\alpha 1$ subunit of horse $\mathrm{Na}$,K-ATPase gene FEBS Letters 250 91-98

Kelly P, Duffy P, Roche JF and Boland MP (1997) Superovulation in cattle: effect of FSH type and method of administration of follicular growth, ovulatory response and endocrine pattern Animal Reproduction Science 46 1-14

Kidder GM (1992) The genetic program for preimplantation development Developmental Genetics 13 319-325

Kidder GM (1993) Genes involved in cleavage, compaction and blastocyst formation. In Genes in Mammalian Reproduction pp 45-71 Ed. RBL Gwatkin. Wiley Liss, New York
Koerber S, Santos AN, Tetens F, Küchenhoff A and Fischer B (1998) Increased expression of NADH-Ubiquinone oxidoreductase chain 2 (ND2) in preimplantation rabbit embryos cultured with $20 \%$ oxygen concentration Molecular Reproduction and Development 49 394-399

Latham KE, Scott CD, Doherty AS and Schultz RM (1995) Igf2r and Igf2 gene expression in androgenetic, gynogenetic, and parthenogenetic preimplantation mouse embryos: absence of regulation by genomic imprinting Genes and Development 8 290-299

Lequarre AS, Grisart B, Moreau B, Schuurbiers N, Massip A and Dessy F (1997) Glucose metabolism during bovine preimplantation development: analysis of gene expression in single oocytes and embryos Molecular Reproduction and Development 48 216-226

Mantovani R, Enright WJ, Keane MG, Roche JF and Boland MP (1993) Effect of nutrition and dose of follicle stimulating hormone (FSH) on superovulatory response in beef heifers Proceedings of 9th Scientific Meeting of Association Europeene de Transfert Embyonnaire, Lyon p. 234

Moloney AP, Almildi AA, Drennan MJ and Caffrey PJ (1994) Rumen and blood variables in steers fed grass silage and rolled barley or sugar cane mollasses-based supplements Animal Feeding Science Technology 50 37-54

Moore GD, Ayabe T, Kopf GS and Schultz RM (1996) Temporal pattern of gene expression of G1-S cyclins and cdks during the first and second mitotic cell cycles in mouse embryos Molecular Reproduction and Development 45 264-275

Morita Y, Tsutsumi O, Oka Y and Taketani Y (1994) Glucose transporter GLUT 1 mRNA expression in the ontogeny of glucose incorporation in mouse preimplantation embryos Biochemical and Biophysical Research Communication 199 1525-1531

Murphy MG, Enright WJ, Crowe MA, McConnell K, Spicer LJ, Boland MP and Roche JF (1991) Effect of dietary intake on pattern of growth of dominant follicles during the oestrus cycle in beef heifers Journal of Reproduction and Fertility 92 333-338

Nolan R, O'Calllaghan D, Duby RT, Lonergan P and Boland MP (1998) The influence of short-term nutrient changes on follicle growth and embryo production following superovulation in beef heifers Theriogenology 50 1263-1274

Overström EW (1996) In vitro assessment of embryo viability Theriogenology 45 3-16

Parr RA, Davis IF, Fairclough RJ and Moss MA (1987) Overfeeding during early pregnancy reduces peripheral progesterone concentration and pregnancy in sheep Journal of Reproduction and Fertility 80 317-320

Parr RA, Davis IF, Miles MA and Squires TJ (1993) Feed intake affects metabolic clearance rate of progesterone in sheep Research in Veterinary Science 55 306-310

Rabiee AR, Lean IJ, Gooden JM, Miller BG and Scaramuzzi RJ (1997) An evaluation of transovarian uptake of metabolites using arterio-venous difference methods in dairy cattle Animal Reproduction Science 48 9-25

Rieger D (1984) The measurement of metabolic activity as an approach to evaluating viability and diagnosing sex in early embryos Theriogenology 21 138-149

Rieger D (1992) Relationships between energy metabolism and development of early mammalian embryos Theriogenology 37 75-93

Rieger D and Guay P (1988) Measurement of the metabolism of energy substrates in individual bovine blastocysts Journal of Reproduction and Fertility 83 585-591

Rieger D, Loskutoff NM and Betteridge KJ (1992a) Developmentally related changes in the uptake and metabolism of glucose, glutamine and pyruvate by cattle embryos produced in vitro. Reproduction, Fertility and Development 4 $547-557$

Rieger D, Loskutoff NM and Betteridge KJ (1992b) Developmentally related changes in the metabolism of glucose and glutamine by cattle embryos produced and co-cultured in vitro. Journal of Reproduction and Fertility 95 585-595

Rondeau M, Guay P, Goff AK and Cooke GM (1995) Assessment of embryo potential by visual and metabolic evaluation Theriogenology 44 351-366

Rosenkrans CF, Jr and First NL (1994) Effect of free amino acids and vitamins on cleavage and developmental rate of bovine zygotes in vitro. Journal of Animal Science 72 434-437

Ross J (1996) Control of messenger RNA stability in higher eukayotes Trends in Genetics 12 171-175

SAS (1989) SAS User's Guide: Statistics SAS Institute, Cary, NC

Shim C, Kwon HB and Kim K (1996) Differential expression of laminin chainspecific mRNA transcripts during mouse preimplantation embryo development Molecular Reproduction and Development 44 44-55 
Shull GE, Greeb J and Lingrel JB (1986) Molecular cloning of 3 distinct forms of the $\mathrm{Na}^{+}, \mathrm{K}^{+}$-ATPase alpha-subunit from rat brain Biochemistry $258125-8132$

Sloan BK, Rowlinson P and Armstrong DG (1988) Milk production in early lactation dairy cows given grass silage ad libitum: influence of concentrate energy source, crude protein content and level of concentrate allowance Animal Production 46 317-331

Takahashi Y and First NL (1992) In vitro development of bovine one-cell embryos: influence of glucose, lactate, pyruvate, amino acids and vitamins Theriogenology 37 963-978

Telford NA, Watson AJ and Schultz GA (1990) Transition from maternal to embryonic control in early mammalian development: a comparison of several species Molecular Reproduction and Development 26 90-100.

Temeles GL, Ram PT, Rothstein JL and Schultz RM (1994) Expression patterns of novel genes during mouse preimplantation embryogenesis Molecular Reproduction and Development 37 121-129

Thomas MG, Bao B and Williams GL (1997) Dietary fats varying in their fatty acid composition differentially influence follicular growth in cows fed isoenergetic diets Journal of Animal Science 75 2512-2519

Tiffin GJ, Rieger D, Betteridge KJ, Yadav BR and King WA (1991) Glucose and glutamine metabolism in preattachment cattle embryos in relation to sex and stage of development Journal of Reproduction and Fertility 93 125-132

Thompson JG, Partridge RJ, Houghton FD, Cox CI and Leese HJ (1996) Oxygen uptake and carbohydrate metabolism by in vitro derived bovine embryos Journal of Reproduction and Fertility 106 299-306

Watson AJ (1992) The cell biology of blastocyst development Molecular Reproduction and Development 33 492-504
Wrenzycki C, Herrmann D, Carnwath JW and Niemann H (1996) Expression of the gap junction gene connexin $43(\mathrm{Cx} 43)$ in preimplantation bovine embryos derived in vitro or in vivo. Journal of Reproduction and Fertility 108 $17-24$

Wrenzycki C, Herrmann D, Carnwath JW and Niemann H (1998a) RNA expression of developmentally important genes in preimplantation bovine embryos produced in TCM supplemented with bovine serum albumin (BSA) Journal of Reproduction and Fertility 112 387-389

Wrenzycki C, Herrmann D, Lemme E, Korsawe K, Carnwath JW and Niemann H (1998b) Determination of the relative abundance of various developmentally important gene transcripts in bovine embryos generated in vitro or in vivo using a semi-quantitative RT-PCR assay Satellite Workshop Proceedings, Embryo Development In Vitro - Current Challenges and Future Concepts, Boston pp 14-15

Wrenzycki C, Herrmann D, Carnwath JW and Niemann H (1999) Alterations in the relative abundance of gene transcripts in preimplantation bovine embryos cultured in medium supplemented with either serum or PVA Molecular Reproduction and Development 53 8-18

Yaakub H, Williams SA, O'Callaghan D and Boland MP (1997) Effect of dietary intake and glucose infusion on ovulation rate and embryo quality in superovulated ewes Journal of Reproduction and Fertility Abstract Series 19 Abstract 151

Yaakub H, O'Callaghan D and Boland MP (1999) Effect of type and quantity of concentrate on superovulation and embryo yield in beef heifers Theriogenology 51 1259-1266 